\title{
Aydın Yöresindeki Sığırlarda Mavidil Enfeksiyonunun (BTV serotip 4, 9 ve 16)

\author{
Serolojik Araştırılması
}

\author{
İrfan ÖZGÜNLÜK $K^{1, a, *}$ \\ ${ }^{1}$ Harran Üniversitesi, Veteriner Fakültesi, Viroloji Anabilim Dalı, Şanlıurfa, Türkiye \\ aORCID: 0000-0002-6003-8612
}

Geliş Tarihi: 16.07.2019

Kabul Tarihi: 21.08.2019

\begin{abstract}
Özet: Bu çalışmada, Aydın ili sığırlarında mavidil enfeksiyonunun serolojik tespiti ve farklı yaş grupları arasında seropozitiflik oranlarının dağııımının belirlenmesi amaçlanmıştır. Bu amaçla, Aydın ilinde bulunan dört özel çiftlikten, yaşları 1 gün ile 9 yıl arasında değişen sığırlardan toplanan serum örnekleri kullanıldı. Sı̆̆ırlar, yaşlarına göre on grupta sınıflandırıldı. Bluetongue virus (BTV) karşı spesifik antikor tespiti amacıyla mikro nötralizasyon tekniğinden faydalanıldı. Çalışmada kullanılan toplam 288 serum örneğinin yapılan laboratuvar tetkikleri neticesinde, BTV tip 4, 9 ve 16 için sırası ile \%33.33 (96/288), \%51.04 $(147 / 288)$ ve \%24.65 (71/288) seropozitiflik oranları belirlendi. BTV seropozitifliği \%64.24 (185/288) olarak tespit edildi. Örneklenen tüm hayvanlarda BTV'nin bir, iki veya her üç tipi için seropozitif hayvanların sayı ve oranları sırasıyla 91 (\%31.60), 59 (\%20.49) ve 35 (\%12.15) olarak tespit edildi. Test sonuçlarına uygulanan istatiksel sonuca dayanarak, bu üç serotipin varlığı ile yaş arasında anlamlı ilişki görülmedi. Sonuçlar, sığırların yaşlarına bakılmaksızın BTV'ye duyarlı olduklarını göstermiştir.
\end{abstract}

Anahtar Kelimeler: Bluetongue, Sı̆̆ır, Seroloji, Aydın.

\section{Serological Investigation of Bluetongue Infection (BTV type 4, 9 and 16) in Cattle in Aydin Province in Turkey}

Abstract: In this study we aimed to serologically determine Bluetongue Virus (BTV) infections and to assess the distribution of seropositivity rates between different age groups in cattle in Aydin province in Turkey. For this purpose, sera samples collected from cattle whose ages ranged from 1 day to 9 years old, in four private farms, found in Aydin province were used. The cattle were classified in ten groups based on their ages. A total of 288 sera were tested for antibodies against the serotypes BTV 4, BTV 9 and BTV 16 by using micro neutralization technique. Seropositivity rates in sampled population for BTV serotype 4, 9 and 16 were found to be $33.33 \%$ (96/288), 51.04\% (147/288) and $24.65 \%(71 / 288)$, respectively. Seroprevalence for BTV were detected as $64.24 \%$ (185/288). Out of all sampled animals, the number and rates of seropositive animals for one, two or three serotypes of BTV were 91 (31.60\%), 59 (20.49\%) and 35(12.15\%), respectively. Based on the statistical results applied to the test results, no statistically significant correlation was found between the presence of these three serotypes and age. The results suggested that cattle are sensitive to BTV irrespective of the age.

Keywords: Bluetongue, Cattle, Serology, Aydin.

\section{Giriş}

Mavidil hastalığı (MD); uluslararası terminolojide Bluetongue Disease (BT) olarak isimlendirilen, Culicoides (bitting midgs) cinsi sinekler ile nakledilen, evcil ve vahşi ruminantların arboviral bir enfeksiyonudur (Ducheyne ve ark., 2007; Saif, 2011). Hastalığın etkeni olan Bluetongue Virusunun (BTV), birbiriyle yakın antijenik yakınlığı bulunan 27 serotipi bildirilmiştir (Mertens, 1999; Saif, 2011; Jenckel ve ark., 2015). BTV koyunlarda beden ısısında artış, ağız mukozasında konjesyon, ödem, hemoraji, hiperemi ve ülserler, koronitis ve topallık ile karakterize bir enfeksiyona neden olur (Maclachlan, 2011; Roy, 2002; Saif, 2011). Buna ilaveten, BTV sığırlarda fötal ölüm, kongenital anomaliler ve yavru atmalarına da sebep olarak döl veriminin düşmesine neden olmaktadır
(Maclachlan, 2011; Murphy ve ark., 1999; Sperlova ve Zendulkova, 2011).

BTV ilk kez 19. yüzyılda Afrika'da görülmesine rağmen ancak 1902'de tanımlanmıştır (Herald, 1954) ve Afrika dışında varlığının bildirildiği ilk yerlerden biride 1943'te Türkiye'ye oldukça yakın bir ada olan Kıbrıs olmuştur. Türkiye'de 1944-1947 yılları arasında Hatay'da ilk kez varlığı rapor edilmiştir. Hatay'da görülen bu salgın, alınan ciddi önlemler sayesinde sonlandırılmıştır. Ancak ikinci salgın 1977'de Ege Bölgesi'nde gözlemlendikten (Urman ve ark., 1979) sonra Marmara ve Akdeniz Bölgelerinde de görülmüş ve bu enfeksiyonlarda etkenin BTV Tip-4 olarak izolasyon ve identifikasyonu yapılmıştır (Yonguc ve ark., 1982). Türkiye'de, BTV enfeksiyonunun daha sonraki salgınlarından günümüze dek yapılan birçok çalışma 
ile etken olarak (serolojik ve/veya virolojik) BTV Tip4, 9 ve 16 tespiti yapılmıştır (Erturk ve ark., 2004).

Bir koyun hastalığı olan mavidil enfeksiyonu, koyunlarda ciddi enfeksiyonlara neden olsa da BT virusunun tek memeli rezervuarı sığırlar olup hastalı̆̆ın epidemiyolojisinde önemli bir yere sahiptir. Bu çalışmada, Aydın ilindeki sığırlarda mavidil enfeksiyonunun prevalansının tespiti ve BTV'nin 4, 9 ve 16 serotiplerinin dağılımının araştırılması amaçlanmıştır.

\section{Materyal ve Metot}

Serum örneklerinin toplanması ve hazırlanması: Çalışmada kullanılan numuneler Aydın yöresinde bulunan sütçü sığır yetiştiriciliği yapılan işletmelerden temin edildi. Bu amaçla, Aydın il sınırları içinde bulunan 4 farklı süt sığırı işletmesine gerçekleştirilen seyahatler neticesinde toplam 288 sığırdan kan numunesi alındı. Toplanan kan numuneleri laboratuvarda işlenerek serum elde edildi (Tablo 1). Bu amaçla, öncelikle sığırların vena jugularisinden bir kanül yardımı ile vakumlu ve silikon içeren tüplere alınan kan 1 gün buzdolabında bekletildi. Bu sürenin sonunda pıhtılaşan kan tüpleri 3000 devirde santrifüj edildi. Silikon tabaka ile kan hücrelerinden ayrılan ve üstte kalan serum bir Pasteur pipeti yardımı ile steril stok tüplerine alındı. Bütün serumlar $56^{\circ} \mathrm{C} 30$ dakika süre ile inaktive edildi ve testte kullanılıncaya kadar $-20^{\circ} \mathrm{C}$ derin dondurucuda muhafaza edildi. $\mathrm{Bu}$ çalışmada örneklenen hiçbir sığır aşılı değildi ve herhangi bir klinik semptom göstermemekteydi.

Virüsler: Nötralizasyon testinde mavidil virüsünün serotipleri (BTV 4, BTV-9 ve BTV-16) kullanıldı. Çalışmada kullanılan kontrol virus suşları Ankara Üniversitesi Veteriner Fakültesi Viroloji Anabilim Dalından temin edildi.

Hücre kültürü: Virüslerin üretilmesi, titrelerinin belirlenmesi ve nötralizasyon testinin bütün aşamalarında Vero hücre kültüründen kullanıldı. Hücre üretme ortamı olarak \%10 fötal dana serumu (FCS) ilave edilmiş DMEM (Dulbecco's minimal essential medium)'dan faydalanıldı.

Serum nötralizasyon testi (SNT): Serolojik teknik olarak kullanılan Serum Nötralizasyon Testi (SNT) önceden bildirildiği şekilde yapıldı (Karaoglu ve ark., 2007). SNT serotip spesifik bir test olup serolojik çalışmalarda oldukça hassas ve güvenilir olduğu bildirilen bir tekniktir (Sperlova ve Zendulkova, 2011). BTV-4, BTV-9 ve BTV-16 spesifik antikor varlığının tespiti için serum örnekleri 1:10 oranında DMEM ile sulandırıldı. Mikro nötralizasyon tabletleri üzerinde her serum numunesi için yan yana iki kuyucuk ayrıldı ve numaralandırıldı. Sulandırılan her serum örneği kendisi için ayrılan ve numaralandırılan bu kuyucuklara $50 \mu$ l konulduktan sonra serum örneklerinin konulduğu kuyucukların üzerine eşit hacimde $(50 \mu \mathrm{ll})$ BTV (100DKID 50 oranında sulandırılmış) ilave edildi. Virüs kontrol (100 $\mu$ l 100DKID50 oranında sulandırılmış virustan konuldu) ve hücre kontrol (100 $\mu$ l DMEM konuldu) için dörder kuyucuk ayrıldı. Mikro nötralizasyon tabletleri $\% 5 \mathrm{CO}_{2}^{\prime}$ li ve $37^{\circ} \mathrm{C}^{\prime}$ lik ortama sahip etüvde bir saat bekletildi. Inkubasyonun sonunda mikro nötralizasyon pleytlerinin tüm kuyucuklarına 300.000 hücre/ml hücre süspansiyonundan (Vero) $50 \mu \mathrm{l}$ konuldu ve tekrar aynı koşullarda inkübatöre kaldırıldı. Her gün hücre kontrol ve virus kontrol invert ışık mikroskobu ile gözlemlendi. Yapılan kontrollerle 4-5. gün sonunda CPE oluşumuna göre test sonuçları değerlendirildi. Öncelikle hücre kontrolde 4/4 CPE negatif, virüs kontrolde ise 4/4 CPE pozitif gözlemlendi. Testte kullanılan bütün BTV serotipleri sitopatolojik etki (CPE) yaparak çoğalmakta idi. Bu sebeple CPE gözlemlenmeyen gözlerde virüsün serum numunesinde bulunan spesifik antikorlar tarafından nötralize edildiği şeklinde yorumlandı ve bu serum numuneleri seropozitif olarak kabul edildi.

İstatiksel analiz: Mavi dil seropozitivite ve yaş grupları arasındaki ilişkinin değerlendirilmesi için SPSS 22.0 programında chi-square $(\chi 2)$ testinden yararlanıldı.

\section{Bulgular}

Test edilen 288 serum örneğinin 185 (\%64.24) adedi BTV'nin bir veya birkaç serotipine karşı seropozitif olduğu belirlendi. Sadece 103 hayvan (\%35.76) BTV'nin hiçbir serotipine karşı spesifik antikor bulundurmadığı tespit edildi (Tablo 1). Tablo 1 incelendiğinde tek bir tip, 2 tip ve her 3 tipe karşı antikor pozitif hayvanların sayısı ve oranları sırası ile 91/288 (\%31.60), 59/288 (\%20.49) ve 35/288 (\%12.15) olduğu görüldü. Bir veya birden fazla BTV serotipine karşı spesifik antikor bulunduran serum örnekleri Tablo 1'de gösterildi. Örneklenen hayvanların yaş dağılımı ve BTV 4, 9 ve 16 tiplerine karşı pozitiflik oranları Tablo 2'de özetlendi. Bütün hayvanlar BTV'nin üç serotipine karşı ayrı ayrı yapılan SNT sonucunda, BTV 4, 9 ve 16 serotipleri için seroprevalans sırası ile \%33.33, \%51.04 ve \%24.65 olarak bulundu (Tablo 2).

Tablo 2'deki veriler incelendiğinde bütün yaş grupları için seropozitifliğin belirlendiği görülmektedir. Serum örneklerinin 76 adedi 6 veya altı yaşından küçük yavrulara ait idi ve bu hayvanlar için BTV serotip 4, 9 ve 16 seropozitiflik oranları sırası ile 19 (\%25.00), 26 (\%34.21) ve 11 (\%14.47) olarak tespit edildi. Serum örneklenen hayvanların 212 adedi ise 7 ay ile 9 yıl arasında değişen yaşta idi ve bu hayvanların 77 (\%36.32)'sinde BTV serotip 4 için, 121 (\%57.08) adedinde için BTV serotip 9 için 
ve 60 (\%28.30) adedi için BTV serotip 16 spesifik antikor varlığı belirlendi (Tablo 2). Yaş grupları arasında seropozitiplik chi-square $(\chi 2)$ testi ile değerlendirildiğinde istatistiksel olarak fark önemsiz olarak $(P>0.05)$ tespit edildi.

Tablo 1. BTV serotip 4, 9 ve 16 için (tekli, ikili ve üçlü) seropozitif hayvan sayısı ve prevalansları.

\begin{tabular}{|c|c|c|c|c|c|c|c|}
\hline \multirow[t]{2}{*}{ Toplam hayvan sayısı } & \multicolumn{3}{|c|}{ Tekli enfeksiyon Adet (\%) } & \multicolumn{3}{|c|}{ İkili enfeksiyon Adet (\%) } & \multirow{2}{*}{$\begin{array}{c}\text { Üçlü enfeksiyon Adet (\%) } \\
\text { BTV-4-9-16 }\end{array}$} \\
\hline & BTV-4 & BTV-9 & BTV-16 & BTV-4-9 & BTV-4-16 & BTV-9-16 & \\
\hline & 19(6.60) & $63(21.86)$ & 9(3.13) & $32(11.11)$ & 10(3.47) & $17(5.90)$ & $35(12.15)$ \\
\hline \multirow[t]{3}{*}{288} & \multirow{2}{*}{\multicolumn{6}{|c|}{$\frac{59 / 288(20.49)}{\text { Toplam pozitif hayvan sayısı ve oranı (\%) }}$}} & $35 / 288(12.15)$ \\
\hline & & & & & & & 185(64.24) \\
\hline & \multicolumn{6}{|c|}{ Toplam negatif hayvan sayısı ve oranı (\%) } & 103(35.76) \\
\hline
\end{tabular}

\section{Tartışma ve Sonuç}

Türkiye için büyük ve küçükbaş hayvan yetiştiriciliği, ulusal hayvan varlığının giderek azalması, hızlı nüfus artışı ve dolayısıyla başta et olmak üzere hayvansal ürünlere olan talebin artması sebebiyle, giderek önem kazanmaktadır. Bazı viral etkenlerin hayvan yetiştiriciliği üzerine etkisi önemli olmaktadır (Murphy ve ark., 1999). Mavidil enfeksiyonu evcil hayvanlar için önem arz eden bir enfeksiyondur. Çalışmamızda BTV antikorlarının tespitinde faydalandığımız SNT oldukça duyarlı ve hızlı sonuç alınan bir test olduğu bildirilmektedir (Sperlova ve Zendulkova, 2011). BTV'nin 27 serotipinden üçünün Türkiye'de varlığı rapor edilmiş (Erturk ve ark., 2004) ve benzer bir coğrafik dağılım gösteren bu 3 serotipin hedef konak olan sığır, koyun ve keçilerde yüksek seroprevalansta görüldüğü vurgulanmaktadır (Burgu ve ark., 1992; Erturk ve ark., 2004). Mavidil hastalığı endemik bölgelerde sığır, koyun ve keçi yetiştiriciliğinde verimliliği düşürerek ciddi ekonomik kayıplara neden olmaktadır (Murphy ve ark., 1999).

Tablo 2. Sığırların yaş dağılımı ve yaş gruplarına göre BTV 4, 9 ve 16 serotiplerinin seroprevalansı.

\begin{tabular}{cccccccc}
\hline \multirow{2}{*}{ Yaş (YıI) } & Hayvan sayısı & \multicolumn{2}{c}{ BTV 4} & \multicolumn{2}{c}{ BTV 9 } & \multicolumn{2}{c}{ BTV 16 } \\
\cline { 3 - 7 } & & Adet & \% & Adet & $\%$ & Adet & \% \\
\hline $\mathbf{0 . 5}$ & 76 & 19 & 25.00 & 26 & 34.21 & 11 & 14.47 \\
$>\mathbf{0 . 5 - 1}$ & 12 & 5 & 41.67 & 8 & 66.67 & 1 & 8.33 \\
$\mathbf{2}$ & 42 & 10 & 23.81 & 22 & 52.38 & 6 & 14.29 \\
$\mathbf{3}$ & 49 & 15 & 30.61 & 21 & 42.86 & 12 & 24.49 \\
$\mathbf{4}$ & 38 & 19 & 50.00 & 21 & 55.26 & 13 & 34.21 \\
$\mathbf{5}$ & 30 & 11 & 36.67 & 17 & 56.67 & 11 & 36.67 \\
$\mathbf{6}$ & 15 & 5 & 33.33 & 13 & 86.67 & 8 & 53.33 \\
$\mathbf{7}$ & 14 & 8 & 57.14 & 10 & 71.43 & 5 & 35.71 \\
$\mathbf{8}$ & 7 & 4 & 57.14 & 6 & 85.71 & 2 & 28.57 \\
$\mathbf{9}$ & 5 & 0 & 0.00 & 3 & 60.00 & 2 & 40.00 \\
\hline Toplam & $\mathbf{2 8 8}$ & $\mathbf{9 6}$ & $\mathbf{3 3 . 3 3}$ & $\mathbf{1 4 7}$ & $\mathbf{5 1 . 0 4}$ & $\mathbf{7 1}$ & $\mathbf{2 4 . 6 5}$ \\
\hline
\end{tabular}

iklim koşulların uygun olması nedeniyle tropik ve subtropik bölgede yaşayan 1400 'den fazla Culicoides türü bulunmaktadır (Coetzee ve ark., 2012; Tabachnick, 2004). Ancak sadece bunlardan
30 kadarının mavidil hastalığının epidemiyolojisinde direkt etkili oldukları bildirilmektedir (Coetzee ve ark., 2012; Gibbs ve Greiner, 1994; Hawkes, 1996; Tabachnick, 2004). Vektörün habitatına bağlı olarak 
mavidil hastalığı vektörün yoğun bulunduğu tropik ve subtropik bölgede $34^{\circ}$ güney ve $53^{\circ}$ kuzey enlemleri arasında yaşayan ruminantlarda görülmektedir (Coetzee ve ark., 2012; Tabachnick, 2004). Türkiye'de, Culicoides türlerinin mavidil hastalığı etkeninin bulaştırılmasından sorumlu oldukları belirtilmekte ve 59 türünün identifiye edildiği bildirilmektedir (Dik ve ark., 2017; Ozgunluk, 2009).

Mavidil hastalığı, döl veriminde düşme, abortlar ve kongenital malformasyonlara neden olan ruminantların önemli bir enfeksiyonudur (Murphy ve ark., 1999). Enfeksiyonunun epidemiyolojisinde rezervuar hayvanlar, vektör ve iklimsel koşullar gibi 3 büyük bileşen belirleyicidir. Nadiren klinik semptom gösteren sığır en önemli rezervuardır (Ducheyne ve ark., 2007; Gibbs ve Greiner, 1994; Gorman, 1990; Lundervold ve ark., 2003). Koyunlarda viremi 30 gün kadar iken (Goldsmit ve ark., 1975) sığırlarda bu süre 100 gün kadardır (Luedke ve ark., 1977). Sığırlarda vireminin bu kadar uzun sürmesi sığırların yalnızca rezervuar olup koyunlar için bir virüs kaynağı olmanın ötesinde bir etki yaratır. Şöyle ki; mavidil enfeksiyonunun biyolojik vektörleri olan Culicoidesler soğuk iklim koşulları nedeniyle kışın aktif değillerdir ve dolayısı ile etken sirkülasyonunun olmadığı bu dönemi virüs sığırlarda viremi şeklinde geçirerek (overwintering, kışı atlatmak) sonraki ilk baharda aktif olan vektör için virüs kaynağı oluşturur (Ducheyne ve ark., 2007; Goldsmit ve ark., 1975; Luedke ve ark., 1977; Tabachnick, 2004). Bu nedenle BTV'nin sığırlardaki durumu önem kazanmakta ve çalışmamızda elde ettiğimiz \%64.24 seropozitiflik oranı oldukça yüksek olup, sığırların bölgede risk faktörü olmaya devam ettiğini düşündürmektedir.

Mavidil hastalığının, Antarktika kıtası hariç bütün dünyada yaygın olduğu bilinmektedir. Mavidil epizootileri Akdeniz havzası, Amerika Birleşik Devletleri (ABD), Ortadoğu Asya ve Avustralya'da varlığı bildirilmiştir (Saif, 2011). Dünyada yapılan serolojik çalışmalarda BTV enfeksiyonunun seroprevalansının farklı ülkelerde \%1.5 (Boyer ve ark., 2007) ile \%90 (Uhaa ve ark., 1990) arasında bir dağılım gösterdiği bildirilmektedir. Türkiye coğrafik konumu itibarıyla Asya ve Avrupa'yı bağlayan bir köprü konumunda olması nedeniyle kritik bir öneme sahiptir. Ducheyne ve ark. (2007), culicoideslerin rüzgarın da yardımı ile BTV'yi uzun mesafelere taşıyacağını bildirmektedir. Bu durum komşu ülkelerde var olan enfeksiyonun Türkiye için risk taşıdığı gibi, bu çalışmanın yapıldığı Ege bölgesi de Avrupa'ya komşu olması nedeniyle kritik öneme sahip olduğuna işaret etmektedir.

BTV için Türkiye'nin farklı lokasyonlarında yapılmış birçok çalışma bulunmaktadır. BTV enfeksiyonu genellikle ülkemizin Güneydoğu, Güney (Akdeniz bölgesi), Batı (Ege Bölgesi) ve Kuzeybatı (Marmara bölgesin) bölgelerinde görülmektedir. Türkiye'de yapılan çalışmalarda sığırlarda mavidil enfeksiyonunun seroprevalansı bölgeler arasında farklılıklar gösterdiği görülmektedir. Bolat (1986) Elâzığ ili sığırlarında yaptığı çalışmada mavidil enfeksiyonu için seropozitiviteyi \%3.53 olarak bildirirken, Girgin ve Yonguç (1988) yaptıkları çalışmada ege bölgesi için seropozitiviteyi \%16 olarak bildirmektedir. Türkiye'nin Güney, Güneydoğu ve Ege Bölgesi sığır, koyun ve keçilerden elde ettikleri serum örneklerinde yapılan bir çalışmada sığırlar için BTV seroprevalansını \%25.5 olarak tespit etmişlerdir (Burgu ve ark., 1992). Ertürk (1994) Türkiye'nin farklı yerleşim birimlerinden toplamış olduğu sığır serumlarının \%1'inde BTV spesifik antikor varlığı saptamışlardır. Erturk (2004) yaptığı diğer bir çalışmada ise sığırlar için BTV seroprevalansını \%57 olarak tespit etmiştir. Yapılan bir çalışmada Güneydoğu Anadolu bölgesinde BTV tip 4 için \%52.58 seropozitiflik rapor edilmiştir (Özgünlük, 2003). Ülkemizin kuzeydoğusunda bulunan 8 ildeki sığırlardan elde ettikleri serumları BTV-4 için tetkik ettikleri bir çalışmada Yıldırım ve Burgu (2005) seropozitifliği \%48.02 olarak elde etmişlerdir. Karaoglu ve ark. (2007) Trakya'daki sığırlarda yaptıkları çalışmada BTV-4, BTV-9 ve BTV-16 için seropozitifliği sırası ile \%69.04, \%71.38 ve \%80.20 olarak belirtmişlerdir. Ozgunluk (2009) Güneydoğu Anadolu bölgesindeki bütün illerden yaptığı örnekleme ile sığırlarda BTV tip 9 ve BTV tip 16 için sırası ile $\% 20.00$ ve $\% 22.03$ seropozitivite bildirmektedir. Yapılan başka bir araştırmada ise Yildirim ve Yilmaz (2010) Türkiye'nin kuzeydoğusunda bulunan iller için BTV-4, BTV-9 ve BTV-16 için seropozitifliği sırası ile \%72.16, \%42.05 ve $\% 36.93$ olarak bildirmektedir. Albayrak ve Ozan (2010) ise Orta Karadeniz Bölgesi için seropozitifliği \%11 olarak tespit belirlemişlerdir. Karaoglu ve ark. (2012), Güneydoğu ve Kuzeydoğu Bölgelerinden toplamış oldukları toplam 1440 kan serumu örneğinde yaptıkları tetkiklerde, \%0.48 ile \%35.18 arasında değişen oranlarda olduğunu tespit etmişlerdir. Yilmaz ve ark. (2012), Kars yöresinde yaptıkları çalışmada sığılar içim \%15.5 seropozitiflik oranını belirlemişlerdir. Kulaç ve ark. (2016) Rize yöresindeki sığırlarda yaptıkları çalışmada seropozitifliği \%25 olarak bildirmektedir.

Daha önce çalışmamızın da yapıldığı Ege Bölgesi ve Türkiye'nin diğer bölgelerinde yapılan çalışmalarda bildirilen veriler, BTV'nin üç serotipininde Türkiye'nin tüm bölgelerinde aktif ve sirküle olmaya devam ettiklerini göstermektedir. Bu görüşümüzü destekleyen diğer bir veri ise, bu çalışmada BTV'nin her üç serotipi için bulunan yüksek seroprevalansın (BTV serotip 4 için \%33.33, 
BTV serotip 9 için \%51.04 ve BTV serotip 16 için \%24.65) yanında, bütün yaş gruplarında yüksek seropozitivitenin tespit edilmiş olmasıdır. İstatistiksel sonucun ışığında, bu durumun yaşa bağ ı duyarlılığın artığı veya azaldığına yönünde değil, BTV ve duyarlı konakçıların varlığı ile vektörün durumu ve ilişkilendirmenin daha doğru bir yaklaşım olacağını düşünmekteyiz. Bu tespite ek olarak, Aydın ilinin Culicoideslerin aktivitesi için uygun olduğunu ve Culicoideslerin vektör olduğu diğer enfeksiyonlar için de risk taşıyabileceği düşünülmektedir.

Çalışmamızda mavidil hastalığının etkeni olan Bluetongue virus'un BTV-4, BTV-9 ve BTV-16 tiplerine karşı spesifik antikor varlığı bütün yaş gruplarında tespit edildi. $\mathrm{Bu}$ sonuç değerlendirildiğinde, iklim şartları da göz önünde bulundurulduğunda, Türkiye'nin batı bölgeleri insektlerin yaşamlarını sürdürmeleri için oldukça uygundur. Bu koşullar altında ciddi önlemler alınmadığı taktirde Culicoides türleri ile nakledilen BTV enfeksiyonu daha da yaygınlaşarak neden olduğu ekonomik kayıpların çok daha yüksek maliyetlere çıkabileceği kaçınılmaz olur.

Sonuç olarak, büyükbaş hayvancılıkta önemli ekonomik kayıplara neden olan BTV, Aydın ilindeki sığırlar arasında yaygın olduğu belirlendi. Türkiye subtropikal bölgede bulunması nedeniyle ülkemizin bütün bölgeleri Culicoideslerin yaşamı için uygun ekolojik şartlara sahip ise de çalışmayı yaptığımız Ege Bölgesi vektör için en konforlu alandır. Vektörleri hedef alan mücadele çok zor ve pratikte her zaman başarı getirmeyebilir. Ayrıca Türkiye'ye komşu ülkelerin BTV ile birlikte tespit edilmiş veya henüz bildirilmemiş birçok insekt vektör kaynaklı egzotik hastalığın varlığı ve bunların her an sınırı geçip ülkemizde enfeksiyonlara neden olabilme riski bulunmaktadır.

$\mathrm{Bu}$ şartlar altında, insekt mücadelesi vakaları biraz düşürse de en etkili mücadele yönteminin mavi dil enfeksiyonu için aşılama olabileceğini düşünmekteyiz. Ülkemizde birden fazla serotipin var olduğu ve bu serotiplerin tam bir çapraz koruma sağlayacak kadar çok antijenik yakınlık göstermediği göz önünde bulundurularak polivalan aşıların formüle edilmesi gerekmektedir. Bu çalışmamızdan elde ettiğimiz sonuçlar aşıların en az trivalan olması gerektiğini göstermektedir.

\section{Kaynaklar}

Albayrak H, Ozan E, 2010: Orta Karadeniz Bölgesinde Ruminant ve Tek Tırnaklılarda Kan Emici Sineklerle Nakledilen Bazı Arboviral Enfeksiyonların Seroprevalansı, Kafkas Univ Vet Fak Derg,16 (1), 33-36.
Bolat $Y, 1986$ : Investigation of antibody of the bluetongue disease in sera of cattle and goat in Elazig. DOGA $T r$ Vet Sci, 10, 235-238.

Boyer TC, Ward MP, Wallace RL, Singer RS, 2007: Regional seroprevalence of bluetongue virus in cattle in Illinois and western Indiana. Am J Vet Res, 68 (11), 1212-1219.

Burgu I, Urman HK, Akça Y, Yonguç AD, Mellor PS, Hambling C, 1992: Serologic survey and vector surveillance for bluetongue in southern Turkey. In "Bluetongue, African Horse Sickness and Related Orbivirusus", Eds; Walton TE, Osburn BI, CRC Press Inc, Boca Raton, Fladelphia, USA. pp. 168-174.

Coetzee P., Stokstad M., Venter EH., Myrmel M., Van Vuuren M., 2012. Bluetongue: A historical and epidemiological perspective with the emphasis on South Africa. Virology Journal, 9, 198.

Dik B, Kuçlu Ö, Öztürk R, 2017: Culicoides Latreille, 1809 (Diptera: Ceratopogonidae) species in the Western Black Sea Region of Turkey, new records for the Turkish fauna. Turk J Vet Anim Sci, 41, 228-237

Ducheyne E, De Deken R, Becu S, Codina B, Nomikou K, Mangana-Vougiaki O, Georgiev G, Purse BV, Hendrickx G, 2007: Quantifying the wind dispersal of Culicoides species in Greece and Bulgaria. Geospatial Health, 1, 177-189.

Ertürk A, 1994: Çesitli serumlarda (koyun, keçi, sıgır) mavidil antikorlarının agar-jel presipitasyon testi ile arastırılması. Etlik Vet Mikrob Derg, 7(5), 1-19.

Erturk A, Tatar N, Kabaklı O, İncoğlu S, Çizmeci SG, Barut FM, 2004: The current situation of bluetongue in Turkey. Vet Ital, 40 (3), 137-140.

Gibbs, EP, Greiner EC, 1994: The epidemiology of bluetongue. Comp Immunol Microbiol Infect Dis, 17(3-4), 207-220.

Girgin H, Yonguc AD, 1988: Serological, etiological and pathological investigation of bluetongue infection in sheep in Turkey. Etlik Vet. Mikrob. Derg, 6, 13-24.

Goldsmit L, Barzilai E, Tarmor T, 1975: The comparative sensitivity of sheep and chicken embrios to bluetongue virus and observations on viremia in experimentally Infected sheep. Aust Vet J, 51, 190-196.

Gorman BM, 1990: The bluetongue viruses. Curr Top Microbiol Immunol, 162, 1-19.

Hawkes RA, 1996: The global distribution of bluetongue. In: "Bluetongue disease in Southeast Asia and the Pacific", Eds; St. Geore, TD and Kegao P, ACIAR Proc. No. 66. pp. 6-14.

Herald RC, 1954: Bluetongue. Bacteriol Rev. 1954, 18(4), 239-253.

Jenckel M, Breard E, Schulz C, ve ark. 2015. Complete coding genome sequence of putative novel bluetongue virus serotype 27. Genome Announc. 12; 3(2): e00016-15.

Karaoglu T, Ozgunluk I, Demir B, Ozkul A, Burgu I, 2007: Seroprevalence of culicoides-borne disease in cattle in European Turkey. Ankara Univ Vet Fak Derg, 54, 121-125.

Karaoglu T, Özgünlük I, Yıldırım Y, Güngör E, Oğuzoğlu Ç, Bilge SD, Özkul A, Alkan F, Akça Y, Burgu I, 2012.: Seroepidemiology of bluetongue virus infection in 
Northeast and Southeast Anatolia, Turkey, Ankara Univ Vet Fak Derg, 59, 289-294.

Kulaç E, Kırmızıgül AH, Yıldırım Y, 2016: Rize Yöresindeki Sığırlarda Mavi Dil Enfeksiyonunun Seroprevalansı. Atatürk Üniv Vet. Bil. Derg, 11(2), 151-158.

Luedke AJ, Jochi MM, Jones RH, 1977: Bluetongue in cattle: effects of Culicoides variipennis transmitted bluetongue virus on pregnant heifers and their calves. Am J Vet Res, 38(11), 1687-1695.

Lundervold M, Milner-Gulland EJ, O'callaghan CJ, Hamblin C, 2003: First evidence of bluetongue virus in Kazakhstan. Veterinary Microbiology, 92, 281-287.

Maclachlan NJ, 2011: Bluetongue: history, global epidemiology, and pathogenesis. Preventive Veterinary Medicine, 102, 107-111.

Mertens PPC, 1999: Orbiviruses and Coltiviruses. In: "Encylopedia of Virology", Eds; Granoff A and Webster RG, second edition. Vol 2, Harcourt Sience and Technology Comp, Academic Press, San Diego, California, USA. pp: 1043-1061

Murphy FA, Gibbs JEP, Horzineck CM, Studdent MJ, 1999: Reoviridae. Veterinary Virology, 3th ed., Academic Press, New York, USA. pp: 391-404.

Ozgunluk I, 2009: A Serologic Investigation of Blue Tongue Virus Serotypes (BTV-9, BTV-16) in Cattle in the Southeastern Anatolia Project Area in Turkey, Journal of Animal and Veterinary Advances, 8(12), 2613-2616.

Özgünlük i, 2003. Güneydoğu Anadolu Projesi (GAP) kapsamındaki bölgede sığırlarda mavidil (BT), akabane (AKA) ve ibaraki (IBA) enfeksiyonlarının seroepidemiyolojisi. Doktora Tezi, Ankara Üniversitesi Sağlık Bilimleri Enstitüsü, Ankara.

Roy P, 2002: Orbivirus. In: "The Springer Index of viruses", Eds; Tidona CD, Darai G,1th edition, Springer-Verlag, Berlin, Germany. pp: 957-963.
Saif LJ, 2011: Reoviridae. In "Fenner's Veterınary Virology", Eds; MacLachlan NJ, Dubovi EJ, 4th Editions, Elsevier Science Publishers. Chapter 15, pp 269-285.

Sperlova A, Zendulkova D, 2011: Bluetongue: a review. Veterinary Medicine, 56, 430-452.

Tabachnick WJ, 2004: Culicoides and the global epidemiology of bluetongue virus infection. Veterinaria Italiana Series, 40, 145-150.

Uhaa IJ, Riemann HP, Thurmond MC, Franti CE, 1990: A seroepidemiological study on bluetongue virus in dairy cattle in the central valley of California. Vet Res Commun, 14(2), 99-112.

Urman HK, Milli U, Mert N, Berkin S, Kahraman MM, Yuce H, Avvuran H, 1979: Congenital Bovine epizootic arthrogryposis and hydranencephaly in Turkey. Ankara Univ Vet Fak Derg, 26, 287-292.

Yıldırım Y, Burgu i, 2005: Kuzeydoğu Anadolu Bölgesi'ndeki sığırlarda mavidil (BT), IBR, PI-3, EBL ve BVD enfeksiyonlarının seroprevalansı. Ankara Üniv Vet Fak Derg, 52, 113-117.

Yildirim Y, Yilmaz V, 2010: Seroprevalence of bluetongue virus 4,9 and 16 serotypes in cattle in various North-eastern provinces of Turkey, Revue Méd Vét, 161, 8-9, 372-375.

Yilmaz V, Yildirim Y, Otlu S, 2012: The seroprevalanca of bluetongue virus infection in cattle in Kars district of Turkey. Israel Journal of Veterinary Medicine, 67, 232-236.

Yonguc AD, Taylor WP, Csonton L, Worrall E, 1982: Bluetongue in western Turkey. Vet Rec, 111, 144146.

*Yazışma Adresi: İrfan ÖZGÜNLÜK Harran Üniversitesi, Veteriner Fakültesi, Viroloji Anabilim Dalı, Eyyubiye kampüsü, 63200, Şanlıurfa, Türkiye.

E-mail: ozgunluk@harran.edu.tr 